\title{
PENGARUH MODEL PEMBELAJARAN CORE BERBANTUAN MIND MAP TERHADAP KEMAMPUAN PEMAHAMAN KONSEP MATEMATIKA SISWA KELAS VIII SMP NEGERI 4 SINGARAJA
}

\author{
A.A.A.S. Pramayudi, N.M.S. Mertasari, I G N. Yudi Hartawan \\ Jurusan Pendidikan Matematika \\ Universitas Pendidikan GaneshaSingaraja, Indonesia \\ e-mail: ayusita1410@gmail.com, Srimertasarinimade@yahoo.co.id, hartawan.math@gmail.com
}

\begin{abstract}
Abstrak
Penelitian ini bertujuan untuk mengetahui pengaruh model pembelajaran CORE (Connecting, Organizing, Reflecting, Extending) berbantuan mind map terhadap pemahaman konsep matematika siswa pada kelas VIII SMP Negeri 4 Singaraja tahun ajaran 2016/2017. Populasi penelitian adalah siswa kelas VIII SMP Negeri 4 Singaraja sebanyak 316 orang siswa. Sampel ditentukan dengan teknik random sampling yang sebelumnya telah dilakukan uji kesetaraan menggunakan uji ANAVA satu jalur sehingga sebanyak 2 kelas terpilih sebagai sampel dengan ukuran sampel 70 siswa yaitu kelas VIII B8 dan VIII B7. Penelitian ini merupakan penelitian semu dengan desain penelitian menggunakan post-test only control group. Data pemahaman konsep matematika siswa diperoleh melalui tes uraian. Hasil penelitian data diperoleh rata-rata skor pemahaman konsep matematika siswa kelas eksperimen adalah 42,675 sedangkan pada kelas kontrol adalah 31,933 . Selanjutnya, data tersebut di analisis menggunakan uji U Mann-Whitney yang dikonversi ke Z karena sampel yang besar sehingga berdistribusi normal dengan taraf signifikansi $5 \%$. Hasil analisis menunjukkan nilai $\left|Z_{\text {tabel }}(1,645)\right|<\mid Z_{\text {hitung }}\left(-2,8623 \mid\right.$. Dengan demikian $H_{0}$ ditolak sehingga, pemahaman konsep matematika siswa yang mengikuti pembelajaran dengan model pembelajaran CORE berbantuan mind map lebih baik dari pemahaman konsep matematika siswa yang mengikuti pembelajaran dengan pembelajaran konvensional. Sehingga dapat disimpulkan bahwa model pembelajaran CORE berbantuan mind map berpengaruh positif terhadap pemahaman konsep siswa kelas VIII SMP Negeri 4 Singaraja.
\end{abstract}

Kata kunci: mind map, model pembelajaran CORE, kemampuan pemahaman konsep matematika.

\begin{abstract}
This research is aimed to know the influence of CORE (Connecting, Organizing, Reflecting, Extending) learning model assisted by mind map towards mathematical conceptual understanding of students in $8^{\text {th }}$ grade of SMP Negeri 4 Singaraja in the academic year of 2016/2017. The population in this study was all of eighth grade students of SMP Negeri 4 Singaraja with amount 316 students. The sampling was determined by random sampling technique before of that the equality was done by using ANOVA one way in which 2 classes were selected as sample group which is of 70 students of VIII B7 and VIII B8. This study is a quasi-experimental research with post-test only control group design. Data of students' were collected by using mathematical conceptual understanding test in the form of essay test. Post-test results showed that the average score of student mathematics conceptual understanding in experimental class was 42,675, while the average score in control class was 31,933. After that, data analysis by using $U$ Mann-Whitney converted to $Z$ because of large sample size with a significance level of $5 \%$. The result showed that $\left|Z_{\text {tabel }}(1,645)\right|<\left|Z_{\text {count }}(-2,8623)\right|$, then the null hypothesis is rejected, so that the ability of mathematical conceptual understanding $8^{\text {th }}$ grade SMP Negeri 4 Singaraja which follows cooperative learning model CORE assisted mind map is better than mathematical conceptual understanding that follows the conventional learning model.It can be concluded that cooperative learning model CORE assisted by mind map given a positive influence with mathematical conceptual understanding VIII SMP Negeri 4 Singaraja.
\end{abstract}

Keywords : mathematical conceptual understanding, mind map, CORE learning model 
Jurnal Pendidikan dan Pembelajaran Matematika Indonesia

Vol. 7 No. 1, Tahun 2018

e-ISSN : 2615-7454

\section{Pendahuluan}

Matematika merupakan salah satu mata pelajaran yang ada pada setiap jenjang pendidikan mulai dari tingkat sekolah dasar hingga perguruan tinggi. Matematika merupakan ilmu universal yang mendasari perkembangan teknologi modern, mempunyai peran penting dalam berbagai disiplin dan memajukan daya pikir manusia. Untuk menguasai dan menciptakan teknologi di masa depan diperlukan penguasaan matematika yang kuat sejak dini (Depdiknas: 2006). Oleh karena itu, matematika merupakan mata pelajaran yang penting untuk dikuasai oleh siswa dalam kegunaannya dalam kehidupan sehari-hari.

Melalui pembelajaran matematika diharapkan siswa secara otomatis dapat tertata nalarnya, dapat berpikir logis, kritis, cermat, analitis, runtut, sistematis, dan konsisten dalam bersikap. Sehingga dapat ditarik kesimpulan bahwa pembelajaran matematika penting untuk diberikan bagi siswa, antara lain disebabkan karena matematika merupakan salah satu ilmu pengetahuan yang menjadi dasar dalam mengembangkan ilmu pengetahuan lainnya.

Menurut Peraturan Menteri Pendidikan Nasional Republik Indonesia Nomor 22 Tahun 2006 Tentang Standar Isi Untuk Satuan Pendidikan Dasar dan Menengah, mata pelajaran matematika bertujuan agar siswa memiliki kemampuan salah satunya yaitu memahami konsep pelajaran.

Pemaparan di atas menunjukkan pentingnya penguasaan materi matematika dapat dikuasai oleh siswa untuk kehidupannya. Salah satu aspek penting dalam proses pembelajaran adalah pemahaman konsep siswa terhadap materi pelajaran. Pemahaman konsep materi merupakan aspek yang penting dalam pembelajaran. Siswa dengan pemahaman konsep yang baik mampu menyelesaiakan permasalahan matematika dengan mudah dan membantu siswa mencapai tujuan pembelajaran matematika.

Namun kenyataannya, pemahaman konsep matematika siswa di Indonesia masih rendah. Hal tersebut dibuktikan dari hasil analisis sebagai berikut : pertama, hasil tes PISA (Programme International for Student Assesment) tahun 2015 yang diikuti oleh 72 negara di seluruh dunia menunjukkan bahwa Indonesia berada di posisi 64 (PISA, 2015). Ranking tersebut meningkat dari tahun 2012 yang berada di posisi 71. Berdasarkan nilai rata-rata, capaian nilai matematika melonjak 11 poin dari tahun 2012. Hasil penilaian oleh PISA dapat digunakan sebagai gambaran mengenai kemampuan pemahaman konsep matematika siswa dikarenakan literasi yang dinilai melalui soal-soal PISA yaitu kemampuan seorang untuk merumuskan, menerapkan dan menafsirkan matematika dalam berbagai konteks, kemampuan melakukan penalaran secara matematis dan menggunakan konsep, prosedur, dan fakta untuk menggambarkan, menjelaskan atau memperkirakan fenomena/kejadian. Jika dilihat dari indikator pemahaman konsep menunjukan bahwa soal dalam PISA secara tidak langsung mengukur kemampuan pemahaman konsep siswa. Adapun indicator pemahaman konsep yaitu : 1) Menyatakan ulang sebuah konsep dengan kata-kata sendiri, dalam literatur PISA dinyatakan kemampuan seseorang untuk merumuskan sehingga dengan indikator pemahaman konsep siswa dapat menjawab soal dengan tepat. 2) Mengidentifikasi yang termasuk contoh dan bukan contoh dari suatu konsep, dalam literatur PISA dinyatakan kemampuan melakukan penalaran secara matematis dan menggunakan konsep sehingga dengan indikator pemahaman konsep siswa dapat menjawab soal dengan tepat, 3) Mengaplikasikan konsep dalam berbagai situasi, dalam literatur PISA dinyatakan menerapkan dan menafsirkan matematika dalam berbagai konteks. Dari pemaparan diatas dapat dinyatakan bahawa soal PISA secara tidak langsung mengidentifikasi pemahaman konsep siswa sehingga dari hasil PISA diketahui bahwa pemahaman konsep siswa kurang.

Berdasarkan nilai rata-rata UN matematika tingkat SMP se-kabupaten Buleleng 3 tahun terakhir mengalami penurunan yang cukup besar. Penurunan rata-rata nilai UN matematika menunjukkan bahwa pemahaman siswa dengan pelajaran matematika setiap tahunnya mengalami penurunan. Soal-soal UN menggambarkan bagaimana pemahaman siswa akan materi yang dipelajari siswa selama mengikuti pelajaran di bangku SMP. Dengan hasil demikian menunjukkan bahwa pemahaman konsep siswa akan materi yang 
telah didapat kurang. Sehingga dengan rendahnya pemahaman konsep siswa dengan materi mengakibatkan siswa sulit menjawab soal-soal pada saat UN.

Hasil penilaian PISA dan nilai rata-rata UN matematika tingkat SMP se-kabupaten Buleleng menunjukkan rendahnya pemahaman konsep matemaika siswa Indonesia. Hai ini tidak sesuai dengan harapan Pemerintah mengingat pendidikan di Indonesia sudah diatur sedemikian rupa sehingga menghasilkan luaran yang memuaskan. Dengan wajib belajar 12 tahun dan juga diberikannya beberapa fasilitas penunjang dalam proses belajar mengajar menunjukkan usaha pemerintah dalam memajukan pendidikan Indonesia.

Usaha pemerintah dalam memajukan pendidikan di Indonesia diharapkan mampu mencerdaskan kehidupan bangsa sesuai dengan tujuan Negara Republik Indonesia dalam pembukaan Undang- Undang Dasar (UUD) Negara Republik Indonesia tahun 1945. Namun kenyataannya usaha tersebut belum juga dapat memberikan hasil yang lebih baik untuk pendidikan Indonesia, hal ini berarti tedapat masalah atau faktor lain yang menyebabkan hal tersebut terjadi.

Kegiatan proses pembelajaran dikelas menjadi pusat dari proses memajukan pendidikan di Indonesia. Proses pembelajaran dikelas menentukan bagaimana hasil/output dari siswa yang diharapkan. Proses belajar mengajar dikelas menjadi salah satu faktor yang menyebabkan pendidikan di Indonesia belum mencapai tujuan yang diinginkan. Paradigma baru dalam pendidikan dan kegiatan pembelajaran saat ini yang menekankan pada student centeredmenuntut adanya keaktifan dari siswa dalam proses pembelajaran. Kegiatan pembelajaran yang berfokus pada student centered menuntut agar siswa dalam proses pembelajaran lebih aktif membangun pemahaman mereka. Komponen dari proses belajar mengajar dikelas salah satunya yaitu pemahaman konsep matematika siswa.

Permasalahan yang dihadapi oleh guru dalam proses pembelajaran perlu dicarikan solusi yang tepat agar permasalahan pemahaman konsep matematika dapat teratasi dengan baik. Salah satu solusi dari permasalahan tersebut adalah dengan menggunakan model pembelajaran yang inovatif dalam pembelajaran. Untuk mensukseskan pelaksanaan pembelajaran, model pembelajaran menjadi sebuah bagian penting dalam mencapai kesuksesan tersebut, oleh krena itu seorang guru hendaknya menentukan jenis model pembelajaran yang tepat (Pujianto, 2015). Penggunaan model pembelajaran yang tepat dapat meningkatkan pemahaman konsep matematika siswa yang berdampak pula pada kualitas pendidikan siswa.

CORE merupakan singkatan dari suatu model pembelajaran yang terdiri dari empat kata yang memiliki kesatuan fungsi dalam proses pembelajaran, yaitu Connecting, organizing, reflecting, extending (Suyatno dalam Wicaksana, 2014). Proses pembelajaran dengan menerapkan Model pembelajaran CORE mengharapkan siswa mampu mengonstruksikan pengetahuannya sendiri dengan cara menghubungkan dan mengorganisasikan pengetahuan baru dengan pengetahuan lama, kemudian memikirkan kembali konsep yang sedang dipelajari serta diharapkan siswa dapat memperluas pengetahuan mereka dalam proses pembelajaran yang berlangsung. Penerapan model pembelajaran CORE dalam proses pembelajaran sangat ditekankan pada aktivitas berpikir siswa, sehingga setiap aspek dalam model pembelajaran ini membantu siswa dalam mengkrontrusikan konsep-konsep dalam materi sehingga memberikan pemahaman konsep yang dipelajari oleh siswa.

Tahapan dalam model pembelajaran CORE juga memberikan ketrampilan siswa dalam mengembangkan konsep dengan mengkontruksikan konsep mereka sendiri. Hal ini dapat lebih efektif dengan bantuan mind map. Mind Map dapat diartikan sebagai proses memetakan pikiran untuk menghubungkan konsep-konsep permasalahan tertentu yang dibentuk dalam bagan yang didalamnya terdapat gambar-gambar cabang-cabang, dan berbagai paduan warna. Dengan mind map, kontruksi dari konsep siswa akan lebih terarah dan efektif dengan bagan yang dibuat sendiri oleh siswa sesuai pemahaman mereka terhadap konsep yang didapat.

Perpaduan model Pembelajaran CORE dan mind map dalam pembelajaran matematika secara teoritis dirasa efektif dalam meningkatkan pemahaman konsep 
matematika siswa dalam tahap pembelajarannya. Tahap Connecting yang menghubungkan konsep lama dengan konsep baru sejalan dengan pembuatan bagan mind map yang menghubungkan konsep-konsep yang diketahui siswa. Dari tahap ini akan membantu meningkatkan kemampuan siswa menyatakan konsep dengan kata-kata sendiri dan juga meningkatkan kemampuan siswa dalam mengidentifikasi atau memberi contoh atau bukan contoh dari konsep. Dengan organizing siswa mengorganisasikan ide-ide yang didapat yang dapat dituangkan dalam pembuatan bagan mind map begitu pula dengan tahap reflecting dengan extending sejalan dengan pembuatan bagan mind map. Dari tahap ini akan membantu siswa dalam mengaplikasikan/menggunakan konsep dengan benar dalam berbagai situasi. Hal ini menunjukkan keterkaitan antara tahap pada proses pembelajaran dengan model pembelajaran CORE terhadap mind map dengan indikator pemahaman konsep.

Berdasarkan pemaparan tersebut, perlu dilakukan penelitian untuk mengetahui apakah pembelajaran CORE berbantuan mind mapberpengaruh terhadap kemampuan pemahaman konsep matematika siswa, sehingga peneliti perlu melakukan penelitian yang berjudul "Pengaruh Model Pembelajaran CORE berbantuan Mind Map terhadap Pemahaman Konsep Matematika Siswa Kelas VIII SMP Negeri 4 Singaraja”.

\section{Metode}

Penelitian ini merupakan penelitian eksperimen dalam kategori penelitian semu (quasi experiment). Penelitian ini bertujuan untuk mengetahui pengaruh model pembelajaran CORE (Connecting, Organizing, Reflecting, Extending) berbantuan mind map terhadap pemahaman konsep matematika siswa kelas VIII SMP Negeri 4 Singaraja.

Populasi dalam penelitian ini adalah siswa kelas VIII SMP Negeri 4 Singaraja non unggulan tahun ajaran 2016/2017. Jumlah siswa kelas VIII SMP Negeri 4 Singaraja adalah 316 orang siswa yang ersebar dalam delapan kelas. Dalam penelitian ini, subjek dari populasi daharuskan setara.

Dalam penelitian ini sampel ditetapkan dari populasi dengan teknik random sampling. Pengambilan sampel dilakukan dengan memilih dua kelas sebagai sampel penelitian. Satu kelas sebagai kelas kontrol dan satu kelas sebagai kelas eksperimen. Pemilihan dilakukan secara acak, sehingga setiap kelas memiliki peluang yang sama untuk menjadi sampel penelitian. Teknik pengambilan sampel dilakukan dengan teknik random sampling. Sebelum dilakukan pengambilan sampel secara acak, akan dilakukan uji kesetaraan dengan menggunakan Analisis Varians (ANAVA) satu jalur. Uji kesetaraan ini dilakukan untuk memperlihatkan bahwa populasi yang digunakan setara. Data yang digunakan dalam melakukan uji kesetaraan ini adalah nilai ulangan akhir semester mata pelajaran matematika siswa kelas VIII semester ganjil tahun ajaran 2016/2017.

Penelitian ini bertujuan untuk menyelidiki pengaruh model pembelajaran CORE (Connecting, Organizing, Reflecting, Extending) berbantuan mind map terhadap pemahaman konsep matematika siswa kelas VIII SMP Negeri 4 Singaraja. Rancangan eksperimen yang digunakan dalam penelitian ini adalah Post-Test Only Control Group Design, di mana kelompok kontrol adalah kelompok dengan pembelajaran konvensional, sedangkan kelompok eksperimen adalah kelompok yang dibelajarkan dengan model pembelajaran CORE (Connecting, Organizing, Reflecting, Extending). Penelitian ini melibatkan variabel bebas (independent variable) dan variabel terikat (dependent variable) yang dijelaskan sebagai berikut:

1. Variabel Bebas

Variabel bebas dalam penelitian ini adalah model pembelajaran, terdapat dua jenis model pembelajaran yaitu model pembelajaran CORE berbantuan mind map untuk kelas eksperimen dan model pembelajaran konvensional yang diterapkan pada kelas control

2. Variabel Terikat 
Variabel terikat dalam penelitian ini adalah kemampuan pemahaman konsep matematika siswa.

Data yang diperlukan dalam penelitian adalah data tentang pemahaman konsep matematika siswa. Instrumen yang digunakan yaitu tes untuk mengukur pemahaman konsep matematika siswa berupa tes uraian. Sebelum dilaksanakan uji coba tes pemahaman konsep matematika siswa, terlebih dahulu post test diuji validitas isinya melaluiexpert judgement (validitas ahli). Setelah diuji oleh validitas ahli dinyatakan bahwa tes pemahaman konsep matematika siswa layak untuk digunakan. Hasil dari ujicoba menunjukkan bahwa tes pemahaman konsep matematika yang terdiri dari 9 soal uraian dinyatakan valid. Kemuadian, peneliti melakukan uji validitas butir tes dengan mengujicobakan tes pemahaman konsep matematika pada siswa kelas VIII 6 SMP Negeri 2 Singaraja. Untuk menghitung validitas butir tes digunakan rumus korelasi product moment.

Hasil validitas konstruk menunjukkan dari 9 butir soal pada tes pemahaman konsep matematika 7 soal yang valid. Tes tersebut kemudian diuji reliabilitasnya dan diperoleh bahwa reliabilitas angket sebesar 0,730 tergolong tinggi. Setelah dinyatakan valid kemuadian dilakukan uji reliabel. Formula yang digunakan adalah formula Alpha Cronbach .

Sebelum dilaksanakan pengujian untuk memperoleh simpulan, data yang diperoleh harus memenuhi uji prasyarat, yaitu:

1. Uji normalitas untuk skor pemahaman konsep matematika siswa dengan menggunakan ujiLiliefors.

2. Uji homogenitas varian untuk kedua kelompok dilakukan dengan menggunakan uji Levene

Apabila kedua syarat tersebut sudah terpenuhi, maka dilanjutkan dengan uji hipotesis menggunakan uji-t satu ekor (statistik parametrik) dengan taraf signifikan $5 \%$. Jika syarat normalitas tidak terpenuhi maka digunakan uji U Mann-Whitney (statistik non-parametrik).

\section{Hasil dan Pembahasan}

Data hasil penelitian disajikan secara analisis deskriptif berupa ukuran pemusatan data yaitu mean, median, dan modus serta ukuran penyebaran data yaitu simpangan (simpangan baku dan varians). Rekapitulasi hasil perhitungan deskriptif dapat diikhtisarkan seperti tabel 1 berikut.

Tabel 1. Rangkuman Analisis Data Skor Kemampuan Pemahaman Konsep Matematika Siswa

\begin{tabular}{cccc}
\hline No & Variabel & \multicolumn{2}{c}{ Kelompok Sampel } \\
\cline { 3 - 4 } & & Eksperimen & Kontrol \\
\hline 1 & $\mathrm{~N}$ & 40 & 30 \\
\hline 2 & $\bar{Y}$ & 42,675 & 31,933 \\
\hline 3 & SD & 15,872 & 12,977 \\
\hline
\end{tabular}

Berdasarkan Tabel 02 terlihat bahwa rata-rata skor pemahaman konsep matematika siswa yang mengikuti pembelajaran dengan model pembelajaranCORE berbantuan mind map pada kelompok eksperimen lebih tinggi daripada rata-rata skor pemahaman konsep matematika siswa pada kelompok kontrol yang mengikuti pembelajaran dengan model pembelajaran konvensional.

Sebelum uji hipotesis dilakukan, terlebih dahulu dilakukan pengujian terhadap normalitas, homogenitas varians.

Hasil uji normalitas data pemahaman konsep matematilka siswa pada kelompok eksperimen menunjukan bahwa $L_{\text {hitung }}=0,1423$. Untuk taraf signifikan $5 \%$ dan banyak data $(n)=40$ diperoleh $L_{\text {tabel }}=0,1401$. Karena $L_{\text {hitung }}>L_{\text {tabel }}$, maka sebaran data pemahaman konsep matematika siswa untuk kelompok eksperimen tidak berdistribusi 
normal. Sedangkan, hasil uji normalitas data pemahaman konsep matematilka siswa pada kelompok kontrol menunjukan bahwa $L_{\text {hitung }}=0,1628$. Untuk taraf signifikan $5 \%$ dan banyak data $(n)=30$ diperoleh $L_{\text {tabel }}=0,1610$. Karena $L_{\text {hitung }}>L$ tabel, makasebaran data pemahaman konsep matematika siswa untuk kelompok control tidak berdistribusi normal. Uji homogenitas varians data pemahaman konsep matematika siswa dianalisis dengan uji Levene dengan kriteria data dikatakan homogen apabila nilai $\mathrm{W}<$ nilai $\mathrm{F}$ tabel. Hasil uji homogenitas varians data pemahaman konsep matematika siswa yaitu $W=2,754$. Berdasarkan tabel untuk taraf signifikansi $5 \%$ dengan dk pembilang $=1$ dan dk penyebut 68 diperoleh $F_{\text {tabel }}=3,982$. Karena $F_{\text {hitung }}<F_{\text {tabel }}$ maka pemahaman konsep matematika siswa pada kelompok eksperimen dan kelompok kontrol mempunyai varians yang homogen.

Berdasarkan hasil uji normalitas dan homogenitas varians diperoleh bahwa data pemahaman konsep matematika siswa untuk kelas eksperimen dan kelas kontrol bukan berasal dari data yang berdistristribusi normal dan memiliki varians yang homogen. Maka dari itu, pengujian hipotesis bisa dilakukan dengan menggunakan uji nonparametrik yaitu uji U Mann-Whitney yang dikonversi menjadi nilai $Z$ karena ukuran sampel besar $(\geq 30)$. Rangkuman hasil pengujian data pemahaman konsep matematika siswa dengan menggunakan uji U Mann-Whitneydisajikan pada Tabel 02.

Tabel 02. Rangkuman Hasil Analisis Uji U Mann-Whitney Data Kemampuan Pemahaman Konsep Matematika Siswa

\begin{tabular}{|l|c|l|l|l|l|}
\hline Kelompok & $\mathbf{N}$ & $\mathbf{R}$ & $\mathbf{U}$ & $\mathbf{Z}$ & $\mathbf{Z}_{\text {tabel }}$ \\
\cline { 1 - 5 } Eksperimen & 40 & 1661 & 359 & $-2,8623$ & 1,645 \\
\hline Kontrol & 30 & 825 & 810 & & \\
\hline
\end{tabular}

Berdasarkan Tabel 03 dapat dilihat bahwa $Z_{\text {hitung }}=-2,8623$ dan $Z_{\text {tabel }}=1,645$. Oleh

karena $\left|Z_{\text {tabel }}\right|<\left|Z_{\text {hitung }}\right|$ maka $\boldsymbol{H}_{\mathbf{0}}$ ditolak dan $\boldsymbol{H}_{\mathbf{1}}$ diterima.Ini berarti bahwa pemahaman konsep matematika siswa yang mengikuti pembelajaran denganmodel pembelajaranCORE berbantuan mind map lebih baik dibandingkan dengan siswa yang mengikuti model pembelajaran konvensional.

\section{PEMBAHASAN}

Berdasarkan hasil pengujian hipotesis diperoleh bahwa kemampuan pemahaman konsep matematika siswa yang mengikuti model pembelajaran CORE berbantuan mind map lebih tinggi daripada siswa yang mengikuti proses pembelajaran konvensional. Hasil pengujian menunjukkan rata-rata skor kemampuan pemahaman konsep siswa yang mengikuti model pembelajaran CORE berbantuan mind map adalah 42,675 sedangkan ratarata skor kemampuan pemahaman konsep siswa yang mengikuti pembelajaran konvensional adalah 31,933. Berdasarkan rata-rata skor pemahaman konsep siswa diatas dapat dinyatakan kemampuan pemahaman konsep matematika siswa pada kelonpok eksperimen yang lebih tinggi daripada kelompok kontrol dapat terjadi karena penerapan model pembelajaran CORE berbantuan mind map menyebabkan siswa menjadi lebih aktif dalam belajar, melatih daya ingat siswa tentang suatu informasi atau konsep, melatih kemampuan menghubungkan yang telah dimilikinya untuk mempelajari konsep yang baru dan melatih kemampuan siswa dalam menyusun ide-ide yang dimilikinya untuk menyelesaiakan permasalahan yang diberikan, serta mengembangkan pemahaman sswa mengenai suatu materi.

Selain itu model pembelajaran CORE memberikan kesempatan bagi siswa untuk berinteraksi dengan teman-temannya, saling bertukar informasi yang dimilikinya, berlatih untuk bersikap demokratis serta berperan aktif dalam mengajukan pendapat, dan mencermati serta memberikan tanggapan terhadap pendapat teman. Sedangkan dengan mind map, siswa menjadi lebih aktif dalam memahami konsep dengan menuangkan kembali pada sebuah bagan yang inovatif sesuai dengan kreasi masing-masing sehingga berdampak konsep yang didapat akan melekat lama pada ingatan dengan cara menuangkannya kembali dengan cara yang unik. Selain itu, model pembelajaran CORE 
berbantuan mind map memberi kesempatan siswa untuk memahami suatu masalah dengan mengingat kembali konsep lama untuk dipadukan dengan konsep baru yang sedang dipelajari, menghubungkan ide-ide penyelesaian dari konsep-konsep yang telah dimiliki, memikirkan kembali penyelesaian masalah yang sedang disusun sehingga, dapat menyelesaiakan masalah yang lebih kompleks.

Pada pembelajaran tatap muka, proses pembelajaran dengan menerapkan model pembelajaran CORE berbantuan mind map dimulai dengan guru menanyakan kehadiran siswa dan menyampaikan judul materi yang akan dibahas dan tujuan pembelajaran yang ingin dicapai. Kemudian guru menginstruksikan siswa untuk membagi kelompok heterogen yang berjumalah 4-5 orang dan guru membagikan LKS kepada setiap masing-masing kelompok. Kemudian guru memberikan contoh salah satu bentuk mind map mengenai gambaran materi yang sedang dibahas sehingga siswa dapat memikirkan gambaran mind map yang akan dibuat. Dalam kelompok, siswa mencermati LKS dan mendiskusikan permasalahan yang terdapat pada LKS dengan cermat dan mencarikan solusi. Dengan diskusi kelompok siswa juga akan terlatih untuk mengemukakan pendapat, mendengarkan dan mencermati pendapat yang disampaikan oleh emannya, bertukar pikiran dengan teman dalam satu kelompok, dan belajar bekerja sama untuk menyelesaiakan suatu prmasalahan.

Selanjutnya guru menggali pengetahuan awal siswa dengan memberikan beberapa pertanyaan yang membimbing siswa untuk mengingat materi sebelumnya yang bersesuaian dengan materi yang akan dipelajari. Dengan menggali kembali pengetahuan awal siswa akan membantu siswa untuk lebih mudah memahami materi yang akan dipelajari dan mempermudah siswa untuk menyelesiakan permasalahan yang diberikan pada LKS. Melalui kegiatan tersebut, sehingga siswa mampu menyatakan ulang sebuah konsep dengan bahasa sendiri dan juga siswa dapat mengidentifikasi contoh dan bukan contoh dari suatu konsep. Kegiatan ini juga memberikan kesempatan siswa mengemukakan pengetahuannya mengenai materi awal yang disimak oleh teman-temanya. Hal ini menyebabkan temantemannya yang menyimak yang lupa dengan materi awal akan mengingat kembali materi awal yang aan digunakan dalam pembelajaran. Kegiatan ini juga menyebabkan siswa aktif dalam kegiatan pemelajaran dan guru menjadi fasilitator yang memberikan pertanyaanpertanyaan yang mengarahkan siswa untuk mengingat kembali informasi yang telah dimiliki dan dipelajari sebelumnya.

Dalam diskusi kelompok siswa mengamati permasalahan yang diberikan pada LKS dan berusaha untuk menyelesaikan dengan pengetahuan awal yang telah dimilikinya. Dalam kegiatan diskusi siswa diharapkan mampu menyusun informasi-informasi ataupun konsep-konsep berdasarkan pengetahuan awal yang dimilikinya. Kemampuan pemahaman konsep siswa terlihat ketika siswa mengingat kembali materi awal yang dimilikinya dan menyusunnya dalam upaya menyelesaiakan permasalahan yang didapat. Kegiatan ini dapat meningkatkan kemampuan siswa dalam mengaplikasikan konsep dalam berbagi situasi. Sehingga, dengan pemahaman tersebut siswa mampu menyusun penyelesaian permasalahan yang diberikan pada dalam LKS.

Kemudian siswa mulai menyelesaiakan permasalahan dengan strategi atau langkahlangkah penyelesaian yang telah disusun sebelumnya. Walaupun siswa sudah mampu untuk menemukan solusi, guru tetap mengarahkan siswa memerikasa kembali strategi atau langkah-langkah penyelesaian yang telah disusun. Hal ini bertujuan untuk meyakinkan siswa dengan langkah yang dimilikinya sudah tepat dan melatih ketelitian siswa dalam mengerjakan sesuatu.

Setelah waktu diskusi selesai, siswa ditunjuk secara acak oleh guru untuk menyampaikan hasil diskusi kelompoknya. Saat perwakilan siswa mempresentasikan hasil diskusi kelompoknya, kelompok lain mencermatinya saat perwakilan siswa tersebut menyampaikan hasil diskusinya. Melalui penyampaian hasil diskusi yang dilakukan oleh perwakilan kelompok yang ditunjuk, siswa dilatih untuk mengemukakan pendapat serta menyimak dan memperhatikan temen mereka yang menyampaikan hasil diskusi kelompoknya. Melalui kegiatan ini pula siswa dilatih untuk memberikan tanggapan terhadap penyampaian hasil diskusi kelompok lain yang berbeda dan pada akhirnya hal tersebut akan 
membuat siswa merasa menemukan konsep-konsep yang sedang mereka pelajari. Setelah itu, siswa diberikan kesempatan untuk bertanya hal-hal yang belum dipahami.

Setelah kegiatan presentasi hasil diskusi kempok telah selesai, kemudian guru memberikan beberapa latihan soal yang dapat memperluas pemahaman siswa mengenai materi yang telah dipelajarinya. Berdasarkan pemahaman yang dimilikinya, siswa membuat langkha-langkah penyelesaian masalah dan menyelesaiakan berdasarkan langkah-langkah penyelesaian yang telah disusun dengan sistematis dan tepat. Pada akhir kegiatan pembelajaran siswa dibimbing membuat kesimpulan dari materi yang dipelajari, salah satunya dengan menyusun mind map. Dengan menyusun mind map sesuai dengan kreasi dan pemahaman konsep yang telah didapat dari pembelajaran akan memantapkan pemahaman konsep yang telah dimiliki ataupun yang didapat dalam pembelajaran. Selanjutya siswa mengerjakan soal kuis yang telah dipersiapkan oleh guru dan juga memberikan pekerjaan rumah (PR) untuk mengerjakan beberapa soal yang berkaitan dengan materi yang telah dipelajarinya.

Berdasarkan hasil pengamatan selama kegiatan penelitian, proses pembelajaran dengan menerapkan model pembelajaran CORE berbantuan mind map memperlihatkan siswa lebih aktif dalam mengikuti proses pembelajaran. Hal ini nampak dari antusias siswa dalam mengikuti proses pembelajaran da keberanian siswa dalam mengemukakan pendapat dan memberikan respon berupa tanggapan atau penyataan atas pertanyaan yang diberikan oleh guru, memberikan tanggapan atas pertanyaan yang disampaikan oleh temannya yang lain atau menyampaiakan pertanyaan apabila terdapat hal-hal yang kurang jelas atau belum dimengerti. Selain itu, siswa juga semakin aktif dalam menyampaikan ide untuk menyelesaikan suatu permasalahan.

Ditinjau dari kegiatan pembelajaran, aktivitas kelompok siswa yang mengikuti model pembelajaran CORE berbantuan mind map lebih aktif dan antusias dalam mengikuti proses pembelajaran. Hal ini tidak lepas dari kegiatan pembelajaran yang di desain dalam bentuk diskusi kelompok yang memungkinkan siswa saling bertukar pendapat dan menyampaiakan pengetahuan yang dimilikinya untuk bersama-sama menyelesaiakan permasalahan yang didapat pada LKS.

Berdasarkan hal tersebut diatas, terlihat bahwa model pembelajaran CORE berbantuan mind map menekankan pada pemahaman konsep siswa dari pembelajaran sebelumnya dan juga kemampuan siswa untuk menyusun langkah-langkah penyelesaian dengan mengorganisasikan konsep yang telah dimiliki. Hal ini menyebabkan pemahaman konsep siswa akan lebih dalam sehingga bermanfaat bagi siswa dalam menyelesaiakan permasalahan yang ditemuinya nanti. Siswa juga akan dapat memahami suatu permasalahan dengan baik sehingga dalam menyusun langkah-langkah penyelesaian dapat secara sistematis dan tepat dan memberikan solusi yang tepat. Hal tersebut dapat melatih ketelitian dan kecermatan siswa dalam menyelesaiakan permasalahan yang diberikan, memikirkan kembali penyelesaian yang telah diperoleh, dan mempeeluas pemahaman menganai materi yang baru dipelajari dengan mengaplikasikan materi yang telah dipelajari untuk menyelesaiakan soal-soal termasuk soal-soal tentang permasalahan dalam kehidupan sehari-hari.

Sejalan dengan penelitian yang dilakukan oleh Pratama Putra (2015), yang memberikan kesimpulan bahwa model pembelajaran CORE memberikan pengaruh yang lebih tinggi terhadap kemampuan komunikasi matematis siswa dari pada yang mengikuti model pembelajaran konvensional. Kemampuan pemahaman konsep tidak terlepas dari kemampuan komunikasi matematis siswa, dengan baiknya kemampuan komunikasi matematis siswa menyebabkan siswa dapat menyampaikan pengetahuan atau konsep yang didapat sehingga dapat mengukur seberapa besar pemahaman siswa terhadap konsep yang didapat dalam pembelajaran. Selain itu berdasarkan penelitian yang dilakukan oleh Eka Widiantari (2016) yang memberikan kesimpulan bahwa kemampuan pemecahan masalah siswa yang mengikuti proses pembelajaran dengan model pembelajaran CORE lebih baik daripada proses pembelajaran dengan model konvensional. Dari hal tersebut diketahui bahwa model pembelajaran CORE berpengaruh terhadap kemampuan 
pemecahan masalah matematika siswa. Kemampuan pemahaman konsep siswa tidak terlepas dari kemampuan pemecahan masalah siswa, kedua hal tersebut saling terkait satu sama lain.kemampuan pemecahan masalah yang baik mengindikasikan bahwa kemampuan pemahaman konsep yang baik pula, dalam penyusunan langkah penyelesaian masalah dapat dilakukan dengan baik maka konsep yang dimiliki telah digunakan dalam penyusunan penyelesaian masalah yang diberikan merupakan bagian dari pemahaman konsep yang dimiliki.

Selain menyebabkan kemampuan pemahaman konsep matematika siswa menjadi lebih baik, penggunaan model pembelajaran CORE berbantuan mind map juga memberikan beberapa dampak positif bagi siswa. Beberapa hal positif tersebut yaitu, 1) setelah melakukan diskusi kelompok, siswa diberikan soal yang lebih aplikatif yang memberikan dampak positif siswa agar mampu menyelesaiakan masalah secara mandiri agar pemahaman siswa akan materi lebih baik melalui perluasan pengetahan tersebut, 2) meningkatkan keakraban antar siswa, serta memotivasi dalam belajar.

\section{Simpulan dan Saran}

Berdasarkan rumusan masalah, hasil analisis data, dan pembahasan penelitian yang telah diuraikan dapat disimpulkan bahwa data skor kemampuan pemahaman konsep matematika siswa yang dianalisis pada taraf signifikan $5 \%$ menunjukkan hasil uji U MannWhitney dengan nilai Z-hitung $=-2,862$ dan nilai Z-tabel $=1,645$, sehingga $\mid Z$-hitung $|>| Z$ tabell maka kesimpuannya $\mathrm{H}_{0}$ ditolak. Hal ini berarti kemampuan pemahaman konsep matematika siswa kelas VIII SMP Negeri 4 Singaraja yang mengikuti proses pembelajaran dengan model CORE berbantuan mind map lebih baik daripada kemampuan pemahaman konsep matematika siswa yang mengikuti proses pembelajaran dengan model pembelajaran konvensional.

Adapun saran yang dapat disampaikan berdasarkan hasil penelitian yang telah dilakukan adalah sebagai berikut 1) Kepada peneliti lain yang tertarik, disaranan untuk melakukan penelitian terhadap penerapan model pembelajaran CORE terhadap kemampuan kognitif matematika yang lain, 2) Kepada praktisi pendidikan matematika khususnya guru mata pelajaran matematika diharapkan untuk mempertimbangkan kembali penerapan model pembelajaran CORE berbantuan mind map dalam proses pembelajaran mengingat pengaruh positif yang diberikan model pembelajaran CORE mind map terhadap kemampuan pemahaman konsep matematika siswa.

\section{Daftar Pustaka}

Abdush Shomad, Zahid. 2014. Keefektifan Model Pembelajaran CORE dan Pairs Check terhadap Kemampuan Penalaran Matematis Siswa Kelas VII. Skripsi Universitas Negeri Semarang.

Arikunto, Suharsimi. 2002. Dasar-Dasar Evaluasi Pendidikan. Jakarta: Bumi Aksara.

Buzan, T. 2005. Buku Pintar Mind Map. Jakarta : Gramedia Pustaka Utama.

Femi O. 2008. Gembira Belajar Dengan Mind Mapping. Jakarta : PT Alex Media Komputindo

Mahayani, Ida. 2013. Implementasi Model Pembelajaran CORE untuk Meningkatkan Kemampuan Koneksi Matematis Siswa Kelas VII D di SMP Negeri 1 Gianyar. Skripsi UNDIKSHA Singaraja : tidak diterbitkan. 
Muharoroh. 2015. Tingkat Efektivitas Model Pembelajaran CORE (Connecting, Organizing, Reflecting and Extending) Bermuatan MLR (Multiple Level RepresentationP pada Materi Tata Nama Alkana, Alkena dan Akuna di SMA Islam Al-Hikmah Mayong Jepara. Skripsi Universitas Islam Negeri Walisongo.

NCTM. 2000. Principles and Standarts For School Mathematics. America: United States of Americal

Peraturan Meteri Pendidikan Nasional. 2006. Peraturan Meteri Pendidikan Nasional Republik Indonesia Nomor 22 tentang Standar Isi Untuk Satuan Pendidikan Dasar dan Menengah. Jakarta: Peraturan Meteri Pendidikan Nasional

Pratama Putra, Agung. 2015. Pengaruh Model Pembelajaran CORE terhadap Kemampuan Komunikasi Matematis Siswa Kelas X SMA Negeri 1 Bebandem. Skripsi UNDIKSHASingaraja : tidak diterbitkan.

Pujianto, Andi. 2015. Pengertian dan Langkah-Langkah Model Pembelajaran Jigsaw.http://www.infoduniapendidikan.com/2015/06/pengertian-dan-langkah-langkahmodel-pembelajaran-jigsaw.html (diakses pada tanggal 4 Pebruari 2016)

Setyawan, Andoko. 2013. Penerapan Model Pembelajaran Connecting-OrganizingReflecting-Extending (CORE) untuk Meningkatkan Kemampuan Pemahaman dan Koneksi Matematis Siswa Sekolah Menengah Atas. Skripsi UPI Bandung : tidak diterbitkan.

Suciptawati, Ni Luh Putu. 2010. Metode Statistik : Nonparametrik. Denpasar. Udayana University Press

Suherman, E. 1993. Evaluasi Proses dan Hasil Belajar Matematika. Jakarta : Universitas Terbuka.

Suherman, dkk. 2003. Strategi Pembelajaran Matematika Kontemporer. Bandung: JICA.

Sugiyono. 2009. Metode Penelitian Kuantitatif Kualitatif dan R\&B. Bandung: CV. Alfabet

Suryabrata,S.2003. Metodelogi Penelitian.Jakarta :PT.Raja Grafindo Persada.

Suyatno. 2009. Menjelajah Pembelajaran Inovatif. Sidoarjo: Masmedia Buana Pustaka.

TIMSS (Trend in Mathematics and Science Study). 2011. Mathematics Framework.Jurnal TIMSS, Volume 1 (hlm.11--27).

Widiantari, Eka. 2016. Pengaruh Penerapan Model Pembelajaran CORE terhadap Kemampuan pemacahan Masalah Matematika Siswa Kelas X SMA Laboratorium Undiksha. Skripsi UNDIKSHA Singaraja : tidak diterbitkan.

Widiyanti, Novi. 2012. Penerapan Model CORE (Connecting, Organizing, Reflecting, Extending) untuk Meningkatkan Aktivitas dan Hasil Belajar Siswa Kelas VIII B di SMP Negeri 1 Sukasada. Skripsi UNDIKSHA Singaraja : tidak diterbitkan. 
Jurnal Pendidikan dan Pembelajaran Matematika Indonesia

Vol. 7 No. 1, Tahun 2018

e-ISSN : 2615-7454

Winda M.W, Putu. 2016. Pengaruh Strategi Think Talk Write (TTW) berbantuan Mind Map terhadap Kreativitas dan Kemampuan Komunikasi Matematika Siswa Kelas X SMA Negeri 3 Singaraja. Skripsi UNDIKSHA 